\title{
Teaching palliative care in undergraduate nursing education
}

\author{
Ensino dos cuidados paliativos na graduação de enfermagem
}

Rafaella Guilherme Gonçalves ${ }^{1}$, Bruna Ruselly Dantas Silveira ${ }^{1}$, Wanesca Caroline Pereira ${ }^{1}$, Lucas Batista Ferreira $^{1}$, Ana Angélica Rego de Queiroz ${ }^{1}$, Rejane Maria Paiva de Menezes ${ }^{1}$

Objective: to identify the teaching of palliative care in undergraduate nursing education. Methods: scoping review in the following databases: Latin American and Caribbean Literature in Health Sciences, Nursing Database, Spanish Bibliographical Index in Health Sciences, Cumulative Index to Nursing \& Allied Health Literature, and Medical Literature Analysis and Retrieval System Online. Results: seventeen articles were included. The content on palliative care is present in education, mainly through elective courses, but also in compulsory subjects and through outreach projects. In developed countries, simulation, clinical immersion/experience and problembased learning strategies are used. Conclusion: evidence of the presence of palliative care in education was identified, especially in elective subjects, whose approach takes place more often in the theoretical context allied to practical experiences.

Descriptors: Palliative Care; Teaching; Nursing; Professional Training; Higher Education Institutions.

Objetivo: identificar o ensino dos cuidados paliativos na graduação de enfermagem. Métodos: scoping review, nas bases de dados Literatura Latino-Americana e do Caribe em Ciências da Saúde, Banco de Dados em Enfermagem, Índice Bibliográfico Español en Ciencias de la Salud, Cumulative Index to Nursing \& Allied Health Literature e Medical Literature Analysis and Retrieval System Online. Resultados: foram incluídos 17 artigos. 0 conteúdo sobre os cuidados paliativos está presente no ensino, principalmente através de disciplinas eletivas, mas também em disciplinas obrigatórias e por meio de projetos de extensão. Nos países desenvolvidos são utilizadas estratégias de simulação, imersão/experiência clínica e da aprendizagem baseada em problemas. Conclusão: foram identificadas evidências da presença dos cuidados paliativos no ensino, sobretudo nas disciplinas eletivas, cuja abordagem ocorre mais no âmbito teórico aliado às experiências práticas.

Descritores: Cuidados Paliativos; Ensino; Enfermagem; Formação Profissional; Instituições de Ensino Superior.

${ }^{1}$ Universidade Federal do Rio Grande do Norte. Natal, RN, Brazil.

Corresponding author: Rafaella Guilherme Gonçalves

Universidade Federal do Rio Grande do Norte. Campus Universitário Lagoa Nova. CEP: 59078-970. Natal, RN, Brazil. E-mail: goncalvesraffaella@gmail.com 


\section{Introduction}

Palliative care is defined by the World Health Organization as an approach that improves the quality of life of patients and their families when facing problems associated with life-threatening illnesses through prevention and relief of suffering, early identification, correct assessment and management of pain and of physical, psychosocial or spiritual problems ${ }^{(1)}$.

Data published by the World Health Organization in 2014 estimate that around 40 million people in the world need palliative care, $78.0 \%$ of whom are living in low- and middle-income countries, and only $14.0 \%$ of the people who need it receive such assistance. This need will continue to grow in view of the processes of epidemiological and demographic transition $^{(1)}$

The World Health Organization presents four obstacles to improving access to palliative care, namely: lack of competence and qualification of health professionals; little knowledge of the population on the subject; cultural and social obstacles (beliefs about pain and death); and the excess of regulations that restrict the use of opioid analgesics ${ }^{(1)}$.

This scenario highlights the need for nursing academics and professionals to understand palliative care. It is known that professional development in this area has become indispensable, since nurses are professionals who care for people throughout their life cycle, in health and disease situations ${ }^{(2)}$. Moreover, assisting patients with serious and life-threatening illnesses requires a humanistic view of their needs and those of their families, self-control before challenges, and commitment to reach the goal of palliative care to promote quality of life and relief of symptoms in a comprehensive perspective ${ }^{(3)}$.

Although it is a professional duty, recent national studies show that nurses ${ }^{(4)}$ and nursing students ${ }^{(5)}$ are poorly qualified to deal with patients in palliative care and coping with the dying and death process. This situation is possibly related to the training process, as the teaching of palliative care in Brazil is little emphasized in undergraduate nursing curricula, as well as in other health professions, with few institutions providing information on the subject ${ }^{(6)}$.

It is understood that it is important to intensify the stimulus to the theoretical and practical teaching of palliative care in higher education institutions, taking into account that the lack of curricular components generates emotional difficulties and feelings of unpreparedness or lack of learning with respect to palliative care ${ }^{(7)}$. Evidence shows that basic training in palliative care is enough to cause a positive impact on the understanding of the theme, on emotional processing, on the management of suffering, and on the care of patients in palliative care and their relatives ${ }^{(2,7)}$.

Thus, given the current relevance of the topic in human health care and the need to expand this knowledge in the training of nursing professionals, whether in national or international scopes, the present study aims to identify the teaching of palliative care in nursing graduation.

\section{Methods}

This is a Scoping Review with the aim to search and map evidence from the literature on a given area in an extended perspective ${ }^{(8-9)}$, precisely the teaching of palliative care in nursing training.

The reference used for the review was The Joanna Briggs Institute for Scoping Reviews and followed the steps: elaboration of the guiding question; identification of relevant studies; selection of studies; data tabulation; and synthesis of results ${ }^{(9)}$. To guide these methodological steps and extract the data from the selected studies, a research protocol was prepared consisting of a guiding question, the objective, eligibility criteria, type of studies to be selected, search strategy, extraction, and presentation of results.

The guiding question established was: What is the scientific production on the training of nurses in palliative care during undergraduate courses? The elaboration of the question followed the acronym PCC, which consists of the identification of the $\mathrm{P}=$ Population (population to be sought in the studies): undergraduate nursing students; $\mathrm{C}=$ Concept (basic concept 
to be examined in the review): training in palliative care; and $\mathrm{C}=$ Context (cultural factors, geographic location, aspects on a certain theme): during graduation $^{(9)}$.

The bibliographic survey was carried out through the portal of the Virtual Health Library (VHL) and the Portal of Periodicals of the Coordenação de Aperfeiçoamento de Pessoal de Nível Superior (CAPES) in August and September of 2018. It included the following sources of information: Latin American and Caribbean Literature in Health Sciences (LILACS), Nursing Database (BDENF), Spanish Bibliographical Index in Health Sciences (IBECS); Cumulative Index to Nursing \& Allied Health Literature (CINAHL); Medical Literature Analysis and Retrieval System Online (MEDLINE). Materials considered gray literature, such as theses, dissertations, books and ordinances, were not included in the research.

The descriptors selected to perform the search were the terms of the Medical Subject Headings (MESH), also included in the Descriptors in Health Sciences (DeCS), were: Ensino/Teaching/Educación; Cuidados Paliativos/PalliativeCare/Cuidados Paliativos; Enfermagem/Nursing/Enfermería. The descriptors were crossed in an uncontrolled way: "Teaching AND Palliative Care AND Nursing", in LILACS, BDENF and IBECS, in the VHL portal, and "Teaching and Palliative Care AND Nursing" in MEDLINE/PubMed and CINAHL, in the portal of CAPES. In the selected databases, the filters we used were texts available in full length and in Portuguese, English and/or Spanish.

The articles of the sample were research papers that had as objective to bring evidences about the teaching of palliative care in undergraduate nursing courses. Repeated publications, those in the form of abstract, letters to the editor, experience reports, literature reviews, articles of reflection, monographs, dissertations, theses and studies whose results on the theme were irrelevant to the purpose of the review were excluded. No time restriction was adopted for the research in order to gather the largest number of studies on the subject.

Initially, titles and abstracts were independently analyzed by two researchers, authors of the study. The decision on the inclusion or not of articles with controversial evaluation was made by consensus between the two authors. Articles that answered the guiding question were selected and read in full length. A descriptive analysis of the data based on Scoping Review was carried out. Figure 1 shows this flow based on the Preferred Reporting Items for Systematic Reviews and Meta-Analysis ${ }^{(10)}$.
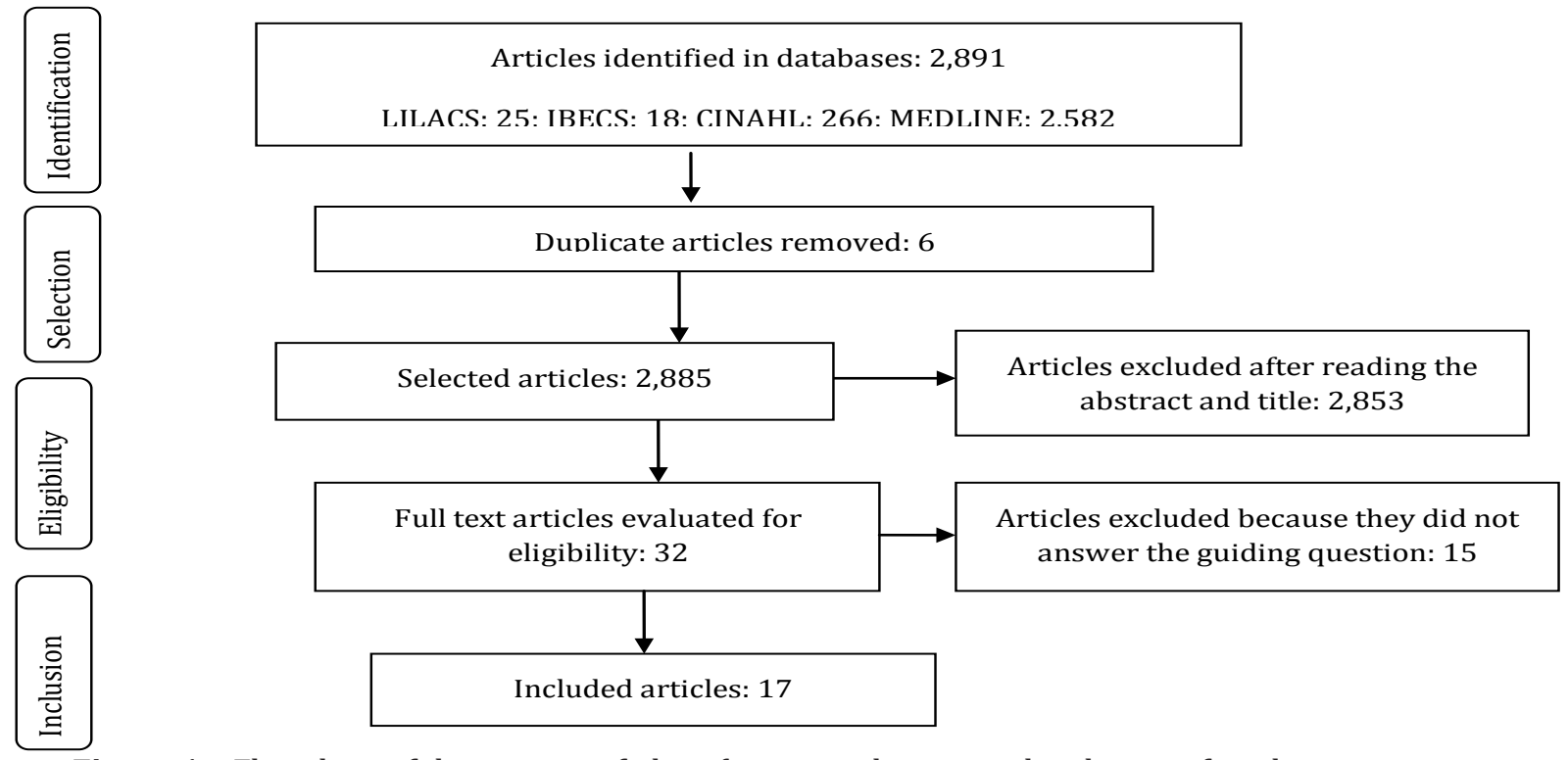

Figure 1 - Flowchart of the process of identification, selection and inclusion of studies 


\section{Results}

The theoretical exploration in the literature resulted in 17 publications ${ }^{(2,7,11-25)}$. The studies were published between the years 2003 and 2017, with the largest volume of publications found in $2017^{(2,11-12)}$, $2016^{(7,13-14)}$, and $2013^{(18-20)}$, with three studies in each year, which denotes the contemporaneity of the theme. Regarding the place of origin of the studies, it was observed that they were from several countries, with predominance of six articles from the United States of America (USA) ${ }^{(13,15-17,20,25)}$, three from $\operatorname{Brazil}^{(2,7,12)}$, two from the United Kingdom ${ }^{(14,19)}$, two from India ${ }^{(11,22)}$, two from Canada ${ }^{(23-24)}$, one from Argentina ${ }^{(21)}$ and one from the Republic of Cyprus ${ }^{(18)}$. As for language of the publications, three were published in Portuguese $\mathrm{e}^{(2,7,12)}$ and 14, in English ${ }^{(13-25)}$.

Regarding the participants of these studies, there were undergraduate students from other professions besides nursing students in eight stu$\operatorname{dies}^{(7,11,13-14,17,21-23)}$; eight studies were conducted only with undergraduate nursing students ${ }^{(12,15-16,18-20,24-25)}$; and, finally, one was conducted with graduate nurses and teachers ${ }^{(2)}$. All the researches were carried out in the context of nursing undergraduate training.

The studies were selected and classified according to the level of evidence ${ }^{(26)}$. Thus, it was identified that of the 17 publications, five were classified in level III, moderate evidence, and 12, in level VI, weak evidence.

\begin{tabular}{|c|c|c|}
\hline Author/Country /Year & $\begin{array}{c}\text { Design/Type of } \\
\text { study }\end{array}$ & Objective of the research \\
\hline Carvalho KK et al/Brasil/2017(2) & $\begin{array}{c}\text { Descriptive/ } \\
\text { qualitative }\end{array}$ & $\begin{array}{l}\text { To know from graduate nurses and teachers the contributions of the educational } \\
\text { process in palliative care at undergraduate training. }\end{array}$ \\
\hline $\begin{array}{l}\text { Sujatha } \quad \mathrm{R}, \\
\text { India/2017 }\end{array}$ & $\begin{array}{c}\text { Descriptive/ } \\
\text { cross-sectional }\end{array}$ & $\begin{array}{l}\text { To evaluate the awareness about palliative care among undergraduates in nursing, } \\
\text { medicine, pharmacy and physical therapy. }\end{array}$ \\
\hline Guimarães TM et al/Brazil/2017 ${ }^{(12)}$ & $\begin{array}{c}\text { Exploratory/ } \\
\text { qualitative }\end{array}$ & $\begin{array}{l}\text { To identify and describe the view of nursing undergraduates on palliative care in } \\
\text { pediatric oncology. }\end{array}$ \\
\hline Costa AP et al/Brazil/2016(7) & $\begin{array}{l}\text { Descritivo/ } \\
\text { qualitativo }\end{array}$ & $\begin{array}{l}\text { To know the experience of undergraduate medicine and nursing students during } \\
\text { consultations to patients in palliative care. }\end{array}$ \\
\hline Head BA et al/EUA $2016^{(13)}$ & $\begin{array}{c}\text { Quasi- } \\
\text { experimental }\end{array}$ & $\begin{array}{l}\text { To report the effort of a university to teach palliative care in a mandatory } \\
\text { interdisciplinary curriculum. }\end{array}$ \\
\hline $\begin{array}{l}\text { Lewis C et al/United King- } \\
\text { dom/2016 }\end{array}$ & $\begin{array}{c}\text { Quasi- } \\
\text { experimental }\end{array}$ & $\begin{array}{l}\text { To evaluate the impact of a simulated intervention on the attitudes of nursing and } \\
\text { medicine students in relation to the end of life. }\end{array}$ \\
\hline Hold JL et al/USA/2015 $5^{(15)}$ & $\begin{array}{c}\text { Exploratory/ } \\
\text { qualitative }\end{array}$ & $\begin{array}{l}\text { To examine the perceptions and experiences of nursing students enrolled in an } \\
\text { optional coursed on palliative care. }\end{array}$ \\
\hline Fabro K et al/USA/2014(16) & $\begin{array}{l}\text { Descriptive/ } \\
\text { mixed method }\end{array}$ & $\begin{array}{l}\text { To describe the development, implementation, and evaluation of an end-of-life } \\
\text { care simulation experience. }\end{array}$ \\
\hline Head BA et al/USA/2014(17) & $\begin{array}{c}\text { Quasi- } \\
\text { experimental }\end{array}$ & $\begin{array}{l}\text { To design, implement and evaluate an interdisciplinary and obligatory curriculum } \\
\text { in oncological palliative care. }\end{array}$ \\
\hline $\begin{array}{l}\text { Charalambou A, Kaite C/Cyprus } \\
\text { Republic/ } 2013^{(18)}\end{array}$ & $\begin{array}{l}\text { Descriptive/ } \\
\text { qualitative }\end{array}$ & $\begin{array}{l}\text { To interpret the experiences of nursing students when they had to deal with } \\
\text { oncological care during their clinical traineeship. }\end{array}$ \\
\hline $\begin{array}{l}\text { Price J et al/United King- } \\
\text { dom } / 2013^{(19)}\end{array}$ & $\begin{array}{l}\text { Descriptive/ } \\
\text { qualitative }\end{array}$ & $\begin{array}{l}\text { To examine a significant learning technique applied to nursing students on } \\
\text { palliative care for children. }\end{array}$ \\
\hline Pullis BC/USA/2013 $3^{(20)}$ & $\begin{array}{c}\text { Descriptive/ } \\
\text { qualitative }\end{array}$ & To report nursing experiences in palliative care. \\
\hline Mutto EM et al/Argentina/2012(21) & $\begin{array}{l}\text { Descriptive/ } \\
\text { quantitative }\end{array}$ & $\begin{array}{l}\text { To analyze experiences, attitudes and training of nursing and medicine students } \\
\text { in end-of-life issues. }\end{array}$ \\
\hline Sadhu S et al/India/2010(22) & $\begin{array}{l}\text { Descriptive/ } \\
\text { cross-sectional }\end{array}$ & To evaluate the knowledge of health students about palliative care. \\
\hline Mckee $\mathrm{N}$ et al/Canada/2009(23) & $\begin{array}{c}\text { Quasi- } \\
\text { experimental }\end{array}$ & $\begin{array}{l}\text { To describe the assessment of a module for undergraduate health sciences } \\
\text { students of learning based on palliative care problems. }\end{array}$ \\
\hline Brajtman S et al/Canada/2007(24) & $\begin{array}{c}\text { Descriptive/ } \\
\text { cross-sectional }\end{array}$ & $\begin{array}{l}\text { To examine the curriculum content and learning needs of nursing students about } \\
\text { end-of-life care. }\end{array}$ \\
\hline Mallory JL/ USA/2003 ${ }^{(25)}$ & $\begin{array}{c}\text { Quasi- } \\
\text { experimental }\end{array}$ & luate the impact of a component in palliative care. \\
\hline
\end{tabular}

Figura 2 - Caracterização dos artigos pesquisados 
The Figure 2 was constructed according to recommendations of the framework used ${ }^{(8-9)}$, presenting a synthesis of the main characteristics and objectives of the studies, and the Figure 3, with the main results and conclusions of the articles found in this scoping review.

\begin{tabular}{|c|}
\hline Main findings and conclusions \\
\hline $\begin{array}{l}\text { The optional course on palliative care in undergraduate nursing } \\
\text { training has contributed to patient care }{ }^{(2)} \text {. }\end{array}$ \\
\hline $\begin{array}{l}\text { There are gaps in the knowledge about palliative care among students, } \\
\text { but nursing students presented a better result because the curriculum } \\
\text { had a module on the subject, and the students received training on } \\
\text { communication and effective assistance in palliative care }{ }^{(11)} \text {. }\end{array}$ \\
\hline $\begin{array}{l}\text { There is insecurity and unpreparedness among nursing students } \\
\text { with respect to provision of care for children with a potentially fatal } \\
\text { cancer }{ }^{(12)} \text {. }\end{array}$ \\
\hline $\begin{array}{l}\text { The development of skills in palliative care and the perception of } \\
\text { the importance of interdisciplinarity only occurred during practical } \\
\text { activities }{ }^{(7)} \text {. }\end{array}$ \\
\hline $\begin{array}{l}\text { The compulsory course in palliative care has resulted in significant } \\
\text { improvements related to knowledge and skills, and readiness for } \\
\text { interprofessional education }{ }^{(13)} \text {. }\end{array}$ \\
\hline $\begin{array}{l}\text { The end-of-life simulation has helped to improve the attitudes of the } \\
\text { students in this context }{ }^{(14)} \text {. }\end{array}$ \\
\hline $\begin{array}{l}\text { The students improved their understanding and application in } \\
\text { nursing knowledge }{ }^{(15)} \text {. }\end{array}$ \\
\hline The end-of-life simulation served as an effective learning experience ${ }^{(16)}$. \\
\hline $\begin{array}{l}\text { Teachers created a interdisciplinary, efficient, sustainable and viable } \\
\text { curriculum on the theme }{ }^{(17)} \text {. }\end{array}$ \\
\hline $\begin{array}{l}\text { The students emphasized the need for adequate preparation at a } \\
\text { theoretical and clinical level to better cope with situations involving } \\
\text { death and dying }{ }^{(18)} \text {. }\end{array}$ \\
\hline $\begin{array}{l}\text { The students felt that the educational visit to the unit of palliative } \\
\text { care for children, combined with a subsequent discussion, evoked } \\
\text { significant learning experiences }{ }^{(19)} \text {. }\end{array}$ \\
\hline $\begin{array}{l}\text { The clinical experience allowed the students to demonstrate the } \\
\text { principles and philosophy of palliative care to relatives and patients } \\
\text { in terminality }{ }^{(20)} \text {. }\end{array}$ \\
\hline The students presented a positive attitude toward terminal patients ${ }^{(21)}$. \\
\hline $\begin{array}{l}\text { There are generalized deficiencies in the understanding of palliative } \\
\text { care and its philosophy, pain management, communication and } \\
\text { interdisciplinary care }{ }^{(22)} \text {. }\end{array}$ \\
\hline $\begin{array}{l}\text { The approach and thinking of the students about palliative care } \\
\text { changed throughout the module; there was a mobilization of } \\
\text { knowledge on the theme and on interprofessionality }{ }^{(23)} \text {. }\end{array}$ \\
\hline $\begin{array}{l}\text { The students maintained positive attitudes towards terminal patients, } \\
\text { had modest levels of knowledge, and reported that more emphasis } \\
\text { should be placed on teaching this subject }{ }^{(24)} \text {. }\end{array}$ \\
\hline $\begin{array}{l}\text { Nursing students who participated in the six-week didactic and } \\
\text { experiential component in palliative care had a positive increase in } \\
\text { their attitudes towards end-of-life care }{ }^{(25)} \text {. }\end{array}$ \\
\hline
\end{tabular}

Figure 3 - Main results and conclusions of the articles searched
Regarding the training of nurses in palliative care, the sampled studies revealed differences in the teaching of this content related to nationality. Research in the United States ${ }^{(13,16-17)}$, Canada ${ }^{(23)}$, and the United Kingdom ${ }^{(14,19)}$ showed greater advances, for example, when evaluating compulsory palliative care curricula in undergraduate nursing education with an interdisciplinary approach, besides studies on teaching and learning strategies with the use of simulations ${ }^{(14,16)}$, clinical immersion/experience ${ }^{(13,18,20,25)}$, and problem-based learning(23).

In Brazil, some advances were observed, however in a punctual way, through elective courses during undergraduate training for nursing students ${ }^{(2)}$ and participation of nursing and medical students in outreach projects ${ }^{(7)}$.

As for the approach of the course about palliative care in teaching, the use of the theoretical appro$\operatorname{ach}^{(2)}$ and of the practical approach ${ }^{(7,18)}$ was observed, but most frequently experiences in theoretical learning coupled with practical experiences ${ }^{(13,15,17,19-20,25)}$.

It is confirmed that content on palliative care is present in education, mainly through elective courses $^{(2,15-16,25)}$, compulsory courses ${ }^{(13,17)}$, and outreach projects ${ }^{(7)}$. In some studies, this was not identified $^{(11,14,23-24)}$.

All the studies that reflected on initiatives to the teaching of palliative care unanimously brought in their results contributions on this approach in several domains of nurse training, with benefits for students, patients and relatives ${ }^{(2,7,17,19-20,23,25)}$.

Among the main contributions, there were significant improvements related to knowledge and understanding of the subject ${ }^{(13,15,19-20,25)}$, ruptures, and the conception of new ways of thinking and caring in harmony with the principles of palliative care $^{(2,15,19-}$ 20,23), development of skills and attitudes inherent to palliative care ${ }^{(7,15,20,25)}$, perception of the importance of interdisciplinarity ${ }^{(7,13,23)}$, emotional balance $\mathrm{e}^{(7,15,23)}$, humanization of $\operatorname{care}^{(7,23)}$, reflections on life and death ${ }^{(23)}$, and personal values ${ }^{(15,25)}$, creation of professional identity ${ }^{(15)}$, self-confidence to care for patients in the 
end of life ${ }^{(16)}$, and the scope of self-accomplishment ${ }^{(18)}$. Some of these studies also reported on difficulties experienced by students due to the insufficient approach of this content in the professional curriculum, such as feelings of insecurity, lack of preparation, fear, sadness and disappointment ${ }^{(12,18,21)}$. Others showed emotional difficulties ${ }^{(18,21)}$, as well as some deficiencies in understanding palliative care $^{(11,23)}$. Thus, the participants' recognition of the need for the theme to be more addressed and better targeted during trai$\operatorname{ning}^{(7,12,18,21,24)}$ tood out in the studies.

\section{Discussion}

The present research presents limitations related to the absence of studies with the premise of evaluating the national or regional reality on the training of nurses in palliative care. Another restriction was the fact that the study was carried out in selected databases, which, possibly, does not allow the generalization of the data.

This study contributes to fostering the necessary transformations in the nursing training process with respect to the focus theme. In addition, it directs further investments in research, discussions, and suggestions for nursing education about palliative care capable of training professionals with the abilities necessary to provide care to patients experiencing life-threatening illnesses and their families.

Studies from several countries reporting on deficiencies in the training of health professionals, especially nursing professionals, were found regarding knowledge and attitudes towards palliative care $^{(12,18,22)}$, but also about the positive evidence of their application in teaching and care $^{(2)}$.

In order to overcome the existing gaps in the training process, incentives to implement the teaching of palliative care in undergraduate curricula have occurred. In this regard, it is noteworthy that, in the year 2000, the End-of-Life Nursing Education Consortium was created in the USA. This is a national education nursing project to improve the training in palliative care, making it readily available and accessible throughout the country ${ }^{(27)}$.

It is noteworthy that in the United Kingdom, studies on palliative care began in the 1960s. Today, this theme is an integral part of university curricula and has become an irreplaceable practice for the local population, and it is an international reference for access and quality of death ${ }^{(19,28)}$. In turn, this is a still distant reality in Brazil, since the development of this area is recent, becoming more evident only in the last ten years ${ }^{(28)}$.

It is observed that the programs in palliative care vary across countries. Each country has different models due to differences in their socioeconomic situation, health policies, and patient and family needs. In developing countries, there is little investment and recognition on the part of the government concerning this area. Furthermore, the cultural question can directly influence the greater investment in curative medicine, when compared to the palliative, and the little training of human resources ${ }^{(28)}$.

It is understood that the educational process in palliative care contributes not only to the construction of spaces for reflection on the issues of providing care for people with life-threatening illnesses, but also enables changes in the way of thinking about care in terminality, recognizing its relevance and the need to consider biopsychosocial aspects ${ }^{(2)}$.

A research conducted in 2014 at two universities in USA agrees in the exploration of the contributions of teaching of palliative care for nursing students showed that elective subjects on palliative care provided students with a comprehensive view of the profession, helped in the interaction, communication and better understanding of patients, and also contributed to personal growth, as it promoted reflections on death, thus increasing self-awareness. In addition, the students considered the teaching of palliative care as of great importance in the nursing curriculum ${ }^{(29)}$.

For these reasons, it is important to create interdisciplinary educational opportunities for students in different health areas, as a way to motivate them in 
this learning, to acquire skills for team practice and to provide quality patient-centered care ${ }^{(13,17)}$.

A research conducted in 2014 in the USA reported on the planning, conduction, and evaluation of an Interdisciplinary Curriculum for Oncology Palliative Care Education by an interdisciplinary team of teachers. This curriculum aims to enable students to apply general principles of interdisciplinary palliative care to cancer patients, with a focus on contents such as collaborative practice, physical, psychosocial, spiritual and cultural care, ethics, legislation and communication $^{(17) .}$

Regarding the contents associated to palliative care at the national level, they are still insufficient ${ }^{(2,7,12)}$. Thus, a greater theoretical approach is necessary, but without leaving aside the practice in the various curricular components to be carried out during undergraduate training, and the development of palliative philosophy in this context ${ }^{(7)}$.

It is important to emphasize that the principles that underlie the palliative care philosophy must exist transversally in undergraduate curricula and during the entire nursing education ${ }^{(7)}$. These are principles that involve skills and areas such as sensitivity to dealing with humans, understanding the different aspects that involve the dying process, such as respect for patient autonomy, skills for dialogue and dealing with feelings, and the emotions that may arise. In addition, feelings of solidarity, social commitment, ethics, interdisciplinary work, acceptance of death as a natural process, and knowledge for symptom management and pain management need to be addressed throughout this ongoing process of learning(2).

In the teaching of this theme, the strategies used should provide meaningful connections between the student, the content, the practical experience and the patient. By unifying theoretical learning, practical experience and palliative care ethics to guide actions, the students improve their understanding and application of knowledge and advance in the creation of professional identity, in order to provide quality palliative care and to promote a good death ${ }^{(15)}$.

The practical approach of palliative care pro- motes the development of skills necessary to implement this philosophy of caring, validating classroom learning ${ }^{(7,13)}$. In addition, it provides students with the creation of their own mechanisms to bring comfort to patients and their families. They lose inhibition, fear, learn to deal with the patient as a person, not as a disease, learn to listen, to guide and teach whatever is necessary and, above all, to support the patients and their families, characterizing true learning of humanization $^{(7)}$.

Given the challenge of finding suitable clinical experiences for this learning, simulations offer an alternative strategy for nursing students to apply the principles of palliative care in an interactive and safe learning environment, causing a positive impact on student attitudes towards the end of life $\mathrm{f}^{(14,16,30)}$.

\section{Conclusion}

It was identified the presence of palliative care in education, especially in elective courses whose approach takes place more in the theoretical scope associated with practical experiences. In addition, initiatives for teaching palliative care result in essential benefits in nurse training.

\section{Acknowledgements}

To the Coordenação de Aperfeiçoamento de Pessoal de Nível Superior the financial support of the Scholarship for Postgraduate training stricto sensu, Master in Nursing.

\section{Collaborations}

Gonçalves RG contributed with the planning and design, writing of the article, analysis and interpretation of the data. Silveira BRD, Pereira WC and Ferreira LB contributed with the writing of the article, analysis and interpretation of the data. Queiroz AAR and Menezes RMP collaborated with the relevant critical review of the intellectual content and final approval of the version to be published. 


\section{References}

1. World Health Organization. Global atlas of palliative care at the end of life [Internet]. 2014 [cited Nov. 26, 2018]. Available from: www.who. int/nmh/Global_Atlas_of_Palliative_Care.pdf

2. Carvalho KK, Lunardi VL, Silva PA, Vasques TCS, Amestoy SC. Educational process in palliative care and the thought reform. Invest Educ Enferm. 2017; 35(1):17-25. doi: http://dx.doi.org/10.17533/ udea.iee.v35n1a03

3. Morais EN, Conrad D, Mattos EM, Cruz SAC, Machado GC, Abreu MO. Palliative care: coping nurses in a private hospital in the city of Rio de Janeiro - RJ. J Res Fundam Care Online. 2018. 2018; 10(2):318-325. http://dx.doi.org/10.9789/21755361.2018.v10i2.318-325

4. Silveira NR, Nascimento ERP, Rosa LM, Jung W, Martins S, Fontes MS, et al. Palliative care and the intensive care nurses: feelings that endure. Rev Bras Enferm. 2018; 69(6):1074-81. doi: http:// dx.doi.org/10.1590/0034-7167-2016-0267

5. Silva RS, Oliveira CCSG, Pereira A, Amaral JB. Care to the person in a terminal process in the perception of the nursing students. Rev Rene. 2015; 16(3):415-24. doi: http://dx.doi. org/10.15253/2175-6783.2015000300015

6. Garcia JBS, Rodrigues RF, Lima SF. Structuring a palliative care service in Brazil: experience report. Rev Bras Anestesiol. 2014; 64(4)286-91. doi: http://dx.doi.org/10.1016/j.bjan.2013.06.007

7. Costa AP, Poles K, Silva AE. Palliative care training: experience of medical and nursing students. Interface (Botucatu). 2016; 20(59):1041-52. doi: http://dx.doi.org/10.1590/1807-57622015.0774

8. Peters MD, Godfrey CM, Khalil H, McInerney P, Parker D, Soares CB. Guidance for conducting systematic scoping reviews. Int J Evid Based Healthc. 2015; 13(3):141-6. doi: http://dx.doi. org/10.1097/XEB.0000000000000050

9. Peters MD, Godfrey CM, Khalil H, McInerney P, Parker D, Soares CB. The Joanna Briggs Institute reviewers' manual 2015: methodology for JBI scoping reviews [Internet]. 2015 [cited Jan. 14, 2019]. Available from: http://joannabriggs. org/assets/docs/sumari/Reviewers-Manual_ Methodology-for-JBI-Scoping-Reviews_2015_ v1.pdf
10. Galvão TF, Pansani TSA, Harrad D. Principais itens para relatar Revisões sistemáticas e Metaanálises: a recomendação PRISMA. Epidemiol Serv Saúde. 2015; 24(2):335-42. doi: http:// dx.doi.org/10.5123/s1679-49742015000200017

11. Sujatha R, Jayagowri, K. Assessment of palliative care awareness among undergraduate healthcare students. J Clin Diagn Res. 2017; 9(11):6-10 doi: dx.doi.org/10.7860/jcdr/2017/29070.10684

12. Guimarães TM, Silva LF, Espírito SFH, Moraes JRMM, Pacheco STA. Palliative care in paediatric oncology in nursing education. Rev Gaúcha Enferm. 2017; 38(1):e65409. doi: http://dx.doi. org/10.1590/1983-1447.2017.01.65409

13. Head BA, Schapmire T, Earnshaw L, Faul A, Hermann C, Jones C, et al. Evaluation of an interdisciplinary curriculum teaching team-based palliative care integration in oncology. J Canc Educ. 2016; 31(2):358-65. doi: http://dx.doi. org/10.1007/s13187-015-0799-y

14. Lewis C, Reid J, McLernon Z, Ingham R, Traynor $M$. The impact of a simulated intervention on attitudes of undergraduate nursing and medical students towards end of life care provision. BMC Palliat Care. 2016; 15(1):1-6. doi: http://dx.doi. org/10.1186/s12904-016-0143-2

15. Hold JL, Blake BL, Ward EN. Perceptions and experiences of nursing students enrolled in a palliative and end-of-life nursing elective: a qualitative study. Nurse Educ Today. 2015; 35(6):777-81. doi: https://doi.org/10.1016/j.nedt.2015.02.011

16. Fabro K, Schaffer M, Scharton J. The development, implementation, and evaluation of an end-of-life simulation experience for baccalaureate nursing students. Nurs Educ Perspect. 2014; 35(1):19-25. doi: http://dx.doi.org/10.5480/11-593.1

17. Head BA, Schapmire T, Hermann C, Earnshaw L, Faul A, Jones $\mathrm{C}$, et al. The Interdisciplinary Curriculum for Oncology Palliative Care Education (iCOPE): meeting the challenge of interprofessional education. J Palliat Med. 2014; 17(10):1107-14. doi: http://dx.doi.org/10.1089/jpm.2014.0070

18. Charalambou A, Kaite C. Undergraduate nursing students caring for cancer patients: hermeneutic phenomenological insights of their experiences. BMC Health Serv Res. 2013; 13(1):1-13. doi: dx.doi.org/10.1186/1472-6963-13-63 
19. Price J, Dornan J, Quail L. Seeing is believing Reducing misconceptions about children's hospice care through effective teaching with undergraduate nursing students. Nurse Educ Pract. 2013; 13(5):361-5. doi: dx.doi.org/10.1016/j. nepr.2012.09.013

20. Pullis BC. Integration of end-of-life education into a community health nursing course. Public Health Nurs. 2013; 30(5):463-7. doi: dx.doi. org/10.1111/phn.12063

21. Mutto EM, Cantoni MN, Rabhansl MM, Villar MJ. A perspective of end-of-life care education in undergraduate medical and nursing students in Buenos Aires, Argentina. J Palliat Med. 2012; 15(1):93-8. doi: http://dx.doi.org/10.1089/jpm.2011.0238

22. Sadhu S, Salins NS, Kamath A. Palliative care Awareness among Indian undergraduate health care students: a needs-assessment study to determine incorporation of palliative care education in undergraduate medical, nursing and allied health education. Indian J Palliat Care. 2010; 16(3):1549. doi: dx.doi.org/10.4103/0973-1075.73645

23. Mckee N, Goodridge D, Remillard F, D'Eon M. Interprofessional palliative care problem-based learning: Evaluation of a pilot module as a teaching and learning method.JInter ProfCare. 2009; 24(2):1947. doi: dx.doi.org/10.3109/13561820903275043

24. Brajtman S, Fothergill-Bourbonnais F, Casey A, Alain D, Fiset V. Providing direction for change: assessing Canadian nursing students learning needs. Int J Palliat Nurs. 2007; 13(5):213-21. doi: dx.doi.org/10.12968/ijpn.2007.13.5.23491
25. Mallory JL. The impact of a palliative care educational component on attitudes toward care of the dying in undergraduate nursing students. J Prof Nurs. 2003; 19(5):305-12. doi: http://dx.doi. org/10.1016/s8755-7223(03)00094-2

26. Melnyk BM, Fineout-Overholt E. Evidencebased practice in nursing \& healthcare: a guide to best practice. Philadelphia: Wolters Kluwer Health; 2011.

27. Gasparro AK, Shaw MD. Integration of palliative care into a nurse practitioner DNP program. J Nurse Pract. 2017; 13(8):383-8. doi: https://doi. org/10.1016/j.nurpra.2017.04.011

28. Victor GHGG. Palliative care around the world. Rev Bras Cancerol [Internet]. 2016 [cited Jan. 13, 2019];62(3):267-70. Available from: http:// www.inca.gov.br/rbc/n_62/v03/pdf/11-resenhacuidados-paliativos-no-mundo.pdf

29. Ballesteros M, Centeno C, Arantzamendi M. A qualitative exploratory study of nursing students' assessment of the contribution of palliative care learning. Nurse Educ Today. 2014; 34(6):1-6. doi: http://dx.doi.org/10.1016/j.nedt.2013.12.010

30. Smith MB, Macieira TGR, Bumbach MD, Garbutt SJ, Citty SW, Stephen A, et al. The use of simulation to Teach Nursing Students and Clinicians Palliative Careand End-of-Life Communication: A Systematic Review. Am J Hosp Palliat Care. 2018; 35(8):114054. doi: dx.doi.org/10.1177/1049909118761386 